\title{
The new Euskalmet coastal-maritime warning system
}

\author{
Santiago Gaztelumendi ${ }^{1,2}$, Joseba Egaña ${ }^{1,2}$, Pedro Liria ${ }^{3}$, Manuel Gonzalez ${ }^{3}$, José Antonio Aranda ${ }^{2,4}$, \\ and Pedro Anitua ${ }^{4}$ \\ ${ }^{1}$ Tecnalia, Energy and Environment Division, Meteorology Area, Miñano, Araba, Basque Country, Spain \\ ${ }^{2}$ Basque Meteorology Agency (Euskalmet), Miñano, Araba, Basque Country, Spain \\ ${ }^{3}$ AZTI-Tecnalia, Marine Division, Lasarte, Gipuzkoa, Basque Country, Spain \\ ${ }^{4}$ Basque Government, Security Department, Directorate of Emergencies and Meteorology, Vitoria-Gasteiz, \\ Araba, Basque Country, Spain \\ Correspondence to: Santiago Gaztelumendi (santiago.gaztelumendi@ tecnalia.com)
}

Received: 14 January 2016 - Revised: 2 May 2016 - Accepted: 3 May 2016 - Published: 10 June 2016

\begin{abstract}
This work presents the main characteristics of the Basque Meteorology Agency (Euskalmet) maritime-coastal risk warning system, with special emphasis on the latest updates, including a clear differentiation on specific warning messages addressing sea conditions for navigation purposes in the first 2 nautical miles, and expected coastal impacts. Some details of the warning bulletin for maritime and coastal risk situations are also presented, together with other communication products and strategies used in coastal and maritime severe episodes at the Basque coast.

Today, three different aspects are included in the coastal-maritime risk warning system in Basque Country, related to the main potential severe events that affecting coastal activities.

- "Galerna" risk relates to a sudden wind reversal that can severely affect coastal navigation and recreational activities.

- "Navigation" risk relates to severe sea state conditions for 0-2 miles, affecting different navigation activities.

- "Coastal impact" risk relates to adverse wave characteristics and tidal surges that induce flooding events and different impacts in littoral areas.
\end{abstract}

\section{Introduction}

National meteorological service (NMS) weather warning systems were initially based on several meteorological parameters with fixed thresholds, addressing specific scientific and technological aspects of interest for forecasters, but not necessarily for near end-users (WMO, 2002). In recent times worldwide NMSs (including Euskalmet) have developed their services towards a more sophisticated system, based on the traffic-light concept. This impact-based approach has more flexible criteria and is specially focused on civil protection and end-users' needs (WMO, 2010). The coastal and maritime warning system in Euskalmet has migrated from simply significant wave height $\left(H_{\mathrm{S}}\right)$ thresholds, to traffic-light thresholds, which always take into consideration significant wave height in the coastal area (0-2 miles) as a key factor (GV, 2004, 2009, 2011; Gaztelumendi et al., 2012).

During the winter of 2013-2014 several deep Atlantic depressions formed northwest of Britain and Ireland, deepening and moving eastwards, resulting in areas of strong winds and generating high waves that affected severely the Irish, British, French, and Iberian coasts. Particularly on the Basque coast several million euros of damages were produced in one of the most harmful episodes ever recorded (Egaña et al., 2014; Gaztelumendi et al., 2014; Egaña and Gaztelumendi, 2014; Gaztelumendi and Egaña, 2014). As a consequence, different developments (both internal and funded through the Basque Security Department) have been carried out in order to achieve a better local characterization of this phenomenon, taking into account different meteorological and oceanographic aspects, including the study of 


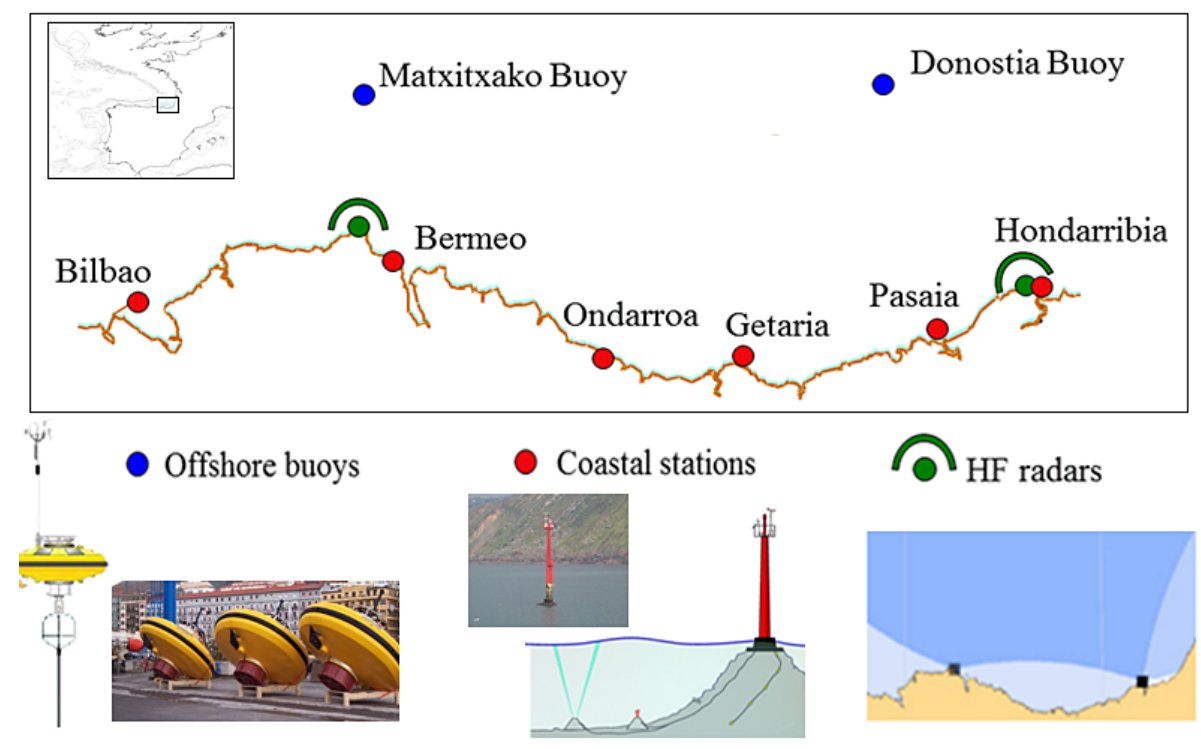

Figure 1. Oceano-meteorological Basque government network.

available parameters in the area from observation networks (Fig. 1), meteorological-oceanographic models and information on damages in Basque coastal areas (Ferrer et al., 2008). At the end some changes in warning system are introduced. In this paper we present the main characteristics of the new Euskalmet coastal-maritime warning system.

First we focus on the redefinition of the maritime-coastal hazards and associated warning systems and particularly in the splitting of "high wave" warning case by introducing the "coastal impact" concept and the overtopping index (Gaztelumendi et al., 2014). Secondly we present the main characteristics of different maritime-coastal operational products generated in Euskalmet. Thirdly, we introduce the communication strategies adopted to communicate and deliver messages to end-users. Finally we show some conclusions.

\section{The maritime-coastal warning system}

It is important to note that other National Weather Services (NWS) in the world also consider "coastal flood" warning usually related to the height of storm tide or wave action, as is the case of USA or France. In other cases "coastal event" warning is present, as is the case of many European NWS under METEOALARM protocol, but usually referring to wind or wave impact, not necessarily related to coastal flood impact (e.g. Spain).

In the case of Euskalmet, the coastal and maritime warnings have migrated from purely significant wave height $\left(H_{\mathrm{s}}\right)$ thresholds to traffic-light thresholds considering always significant wave heights close to the coast ( $0-2$ miles). The Basque coastal-maritime risk warning system includes different meteorological-oceanographic adverse situations af- fecting coastal sea waters ( $0-2$ miles) and littoral areas, during which is possible to have damages in ports, coastal structures, promenade areas, coastal roads, vessels, and different degrees of disturbances in the performance of different activities at sea, ports, beaches, and the shoreline area. During most harmful episodes personal losses are possible. Three different warnings causes are considered:

- "Galerna" refers to a sudden wind reversal affecting the Basque Country littoral area. Such sudden changes in wind speed and direction can cause problems to beach users and small boats during coastal navigation. This meteorological phenomenon is a particular coastal trapped disturbance (CTD) that takes place dominantly during the summer on the northern costs of Spain (GV, 2014; Gaztelumendi et al., 2011). Particular reference conditions, warning/alert/alarm thresholds, and general impact considerations are shown in Fig. 2 (GV, 2014). In this case the impacts usually come from minor incidents related to beach users and recreational sea activities around beaches during the summertime (Fig. 3).

- "Navigation" includes risky conditions motivated primarily by NW gales and other meteorologicaloceanographic episodes that promote worsening sea conditions from waves and wind (Egaña et al., 2010, 2011, 2014; Gaztelumendi et al., 2014) and potentially a dangerous situation for navigation in the first few miles (GV, 2014; Gaztelumendi et al., 2012). Particular reference conditions, warning/alert/alarm thresholds, and general impact considerations are shown in Fig. 2 (GV, 2014). It should be noted that in certain moments and under some circumstances (usually during summer), during which a large number of non-professional sailors 


\begin{tabular}{|c|c|c|c|}
\hline 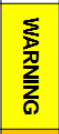 & $\begin{array}{c}\text { Sea conditions: abrupt change of wind to } \\
\text { northwest raging with force } 6 \text {. } \\
\text { Land conditions: sudden wind reversal to } \\
\text { northwest, rising suddenly with strong gusts } 60 \text { - } \\
90 \mathrm{~km} / \mathrm{h} \text { on the coast. }\end{array}$ & $\begin{array}{c}\text { Rough sea or significant wave } \\
\text { height in coast between } 5 \text { and } 3.5 \\
\text { meters. }\end{array}$ & $\begin{array}{l}\text { Overtopping indexes values of } 5,75 \\
\text { and } 7 \text { meters. }\end{array}$ \\
\hline 觉 & $\begin{array}{l}\text { Sea conditions: abrupt change of wind to } \\
\text { northwest raging with force } 7 \text {. } \\
\text { Land conditions: sudden wind reversal to } \\
\text { northwest, rising suddenly with strong gusts } \\
\text { above } 90-120 \mathrm{~km} / \mathrm{h} \text { on the coast. }\end{array}$ & $\begin{array}{l}\text { Very rough sea or significant wave } \\
\text { height in coastal waters of between } \\
5 \text { and } 7 \text { meters. }\end{array}$ & $\begin{array}{l}\text { Overtopping indexes values of } 6,50 \\
\text { and } 8 \text { meters. }\end{array}$ \\
\hline 超 & $\begin{array}{l}\text { Sea conditions: abrupt change of wind to } \\
\text { northwest raging with force } 8 \text { or above. } \\
\text { Land conditions: sudden wind reversal to } \\
\text { northwest, rising suddenly with strong gusts } \\
\text { above } 120 \mathrm{~km} / \mathrm{h} \text { on the coast. }\end{array}$ & $\begin{array}{l}\text { High sea or significant wave height } \\
\text { from } 7 \text { meters coast. }\end{array}$ & $\begin{array}{l}\text { Overtopping indexes values of } 7,25 \\
\text { and } 8 \text { meters. }\end{array}$ \\
\hline 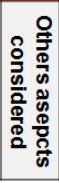 & $\begin{array}{l}\text { Day (beginning or end of summer, August, .). } \\
\text { o Time when Galerna is expected (beach time } \\
\text { or not). } \\
\text { o Weekend or holiday time. } \\
\text { o Sport or special activities organized in } \\
\text { beaches. }\end{array}$ & $\begin{array}{l}\text { Sea general conditions. } \\
\text { Type of waves (swell, wind waves, } \\
\text { cross, chaotic ... ). } \\
\text { Wave characteristics (significant wave } \\
\text { height, peak height, period ... ) } \\
\text { Sports or special activities organized at } \\
\text { sea. }\end{array}$ & $\begin{array}{l}\text { Wind waves and swell characteristics } \\
\text { around maximum tide time. } \\
\text { Peak wave period time. } \\
\text { - Schedule and intensity of the tides and } \\
\text { river flows. } \\
\text { Day and hour (weekend, night time, } \\
\text { summer, etc.). }\end{array}$ \\
\hline
\end{tabular}

Figure 2. Coastal-maritime general considerations and reference thresholds for coastal-maritime warning/alert/alarm in Euskalmet case.
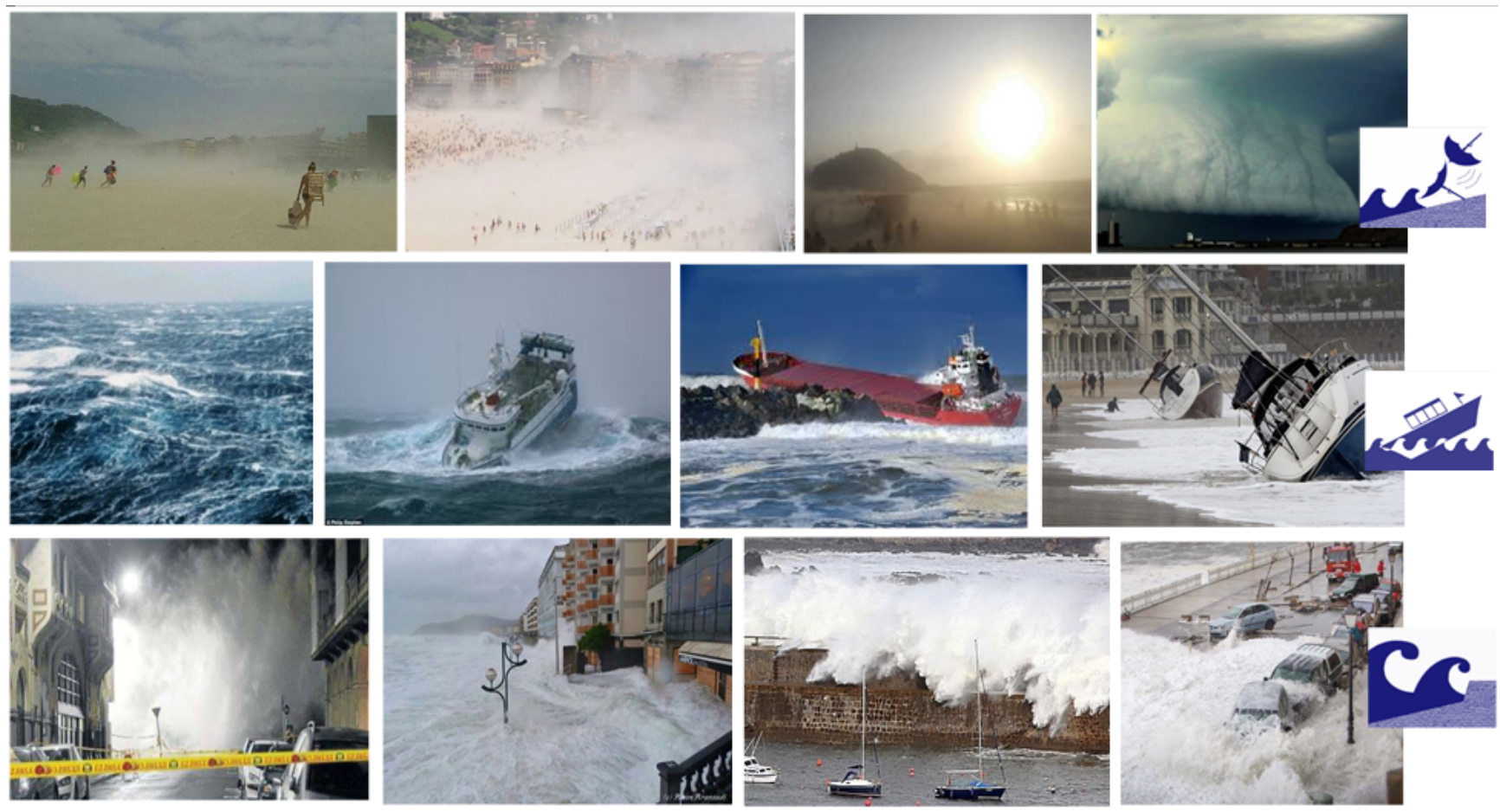

Figure 3. Some illustrative images from coastal-maritime hazards in Basque Country, from top to bottom panels: "galernas", "navigation" and "littoral impact".

and beach users are affected, reference thresholds become lower. In this case the worst impacts are related to the stop of the fishing activity and boat damages (Fig. 3).

- "Coastal impact" is produced when meteorologicaloceanographic conditions generate more or less energetic sea wave run-up. The characterization of these situations is complex; different meteorologicaloceanographic parameters (significant wave height, swell, peak period, tide, etc.) and coastal configuration factors (slope and orientation, among others) must be considered. For this reason the so-called overtopping index (similar to a flood index) is introduced (Liria et al., 2014; Stockdon et al., 2006), incorporating the effects 
of wave height, period, tide, and average characteristics of the Basque coast. Overtopping indexes ( $I$ and $I_{\max }$ ) can be interpreted as the height that the water can reach on the coast due to the combined effect of tide and waves. $I$ is the height that $2 \%$ of waves may exceed, and $I_{\max }$ is the maximum height that the largest wave can reach. Particular reference conditions, warning/alert/alarm thresholds, and general impact considerations are shown in Fig. 2 (GV, 2015). In this case the impact comes from direct waves push and floods, provided information is absolutely relevant to minimize damage by withdrawing vehicles, closing roads and coastal promenades, and physically protecting exposed areas (Fig. 3).

\section{Maritime-coastal products}

Different meteorological-oceanographic observation and modelling systems are available and, more or less, in public domain from diverse sources, have different initiatives such as the Copernicus Marine Environment monitoring system, EModNet, MyOcean, or MyCOAST. In some of these initiatives for the Bay of Biscay area, Euskalmet, Tecnalia R \& I, and AZTI-Tecnalia play an essential role (Ferrer et al., 2008, 2009; Gaztelumendi et al., 2010). In the Basque Country case we have observation and forecasting capabilities from two main sources, on the one hand those implemented and operated by Euskalmet and the Basque government, and on the other hand from some Spanish institutions, mainly Puertos del Estado. Today, the primary observation data sources used in the Basque coastal-maritime warning system come from the Basque meteorological-oceanographic observation system (Fig. 1). In the forecast case we use different sources, including operational meteorological local area modelling systems and waves models from Euskalmet (Gaztelumendi et al., 2008). All this information is used as the basis to prepare different operational products (automatic and nonautomatic).

Effective warning information systems must be short, concise, understandable, and actionable, answering the questions of "what?", "where?", "when?", and "why?", and depending on the severity, "response measurements" must be included (WMO, 2002, 2010). For this purpose different products have been prepared (Gaztelumendi et al., 2016). The most relevant ones are the maritime-coastal official forecast bulletin (daily issue) and the maritime-coastal warning bulletin (issued only in severe weather situations).

The maritime-coastal warning bulletin includes three sections for causes, prediction, and observation data. The "causes" section includes the type or types of phenomena according to predefined adverse weather categories. The "prediction" section includes, for each affected day and warning episode, a short sentence with cause, colour level, time period, affected area, and an explanatory and concise text de- scribing the particular forecasted situation and probability of occurrence. The "observation" section includes, if needed, a text for registered data or observations about a particular event.

The maritime-coastal forecast bulletin includes detailed $D$ and $D+1$ forecast for the first two miles, including description of sea state, wind, wind waves, and swell (using Beaufort and Douglas) for $D$ and $D+1$. This product also includes information for visibility, water temperature, and tides for the ports of Bilbao and Pasaia (Fig. 1), and the rising and setting of the sun. Some graphics are also available for 6days-ahead meteorological-oceanographic trends and maps for forecasted high-resolution sea-level pressure, fronts, and wind with a time horizon of 3 days.

This information is included within the warning email that is sent prior to the forecasted event to specific users and is also available on the Euskalmet website for general public information $(\mathrm{GV}, 2015)$. In red and orange scenarios (occasionally in yellow level), different specific products and messages are prepared for media (radio, TV, newspapers) focusing on what is happening or going to happen and why/what to do to minimize harm. Press releases are written clearly and concisely, explaining the origin of the phenomenon in question, levels of risk, potential impact, and scope of the adverse event.

In Euskalmet case social networks are widely used for severe weather communication (Gaztelumendi et al., 2013, 2015). Messages for Twitter are prepared in headline mode, summarizing the most important aspects, and, depending on the event, more descriptive information and self-protection information for public safety. Twitter is especially interesting for real-time tracking $24 \mathrm{~h}$ a day 365 days a year, transferring forecast and observations from meteorologicaloceanographic Basque network (Fig. 1), and impact data using short texts, photos, videos, maps, and graphs. In case of high predictability or special severity some extended products for temporal horizons beyond $D+3$ are prepared.

\section{Communication strategies}

Effective coastal-maritime early warnings have to be communicated and disseminated to people to ensure they are warned in advance of impending hazardous events and to facilitate emergencies, civil protection, and other authority actions (see Gaztelumendi et al. (2016) for more details). In the Euskalmet case, warning information (via mail and web) are routinely updated at 10:30 and 19:30 LT (or whatever time is needed). All products are written in Spanish and Basque languages. Warning information is disseminated to the population and different public agents (coastal municipalities, Red Cross, marine clubs, beach services, etc.) through the Emergencies (SOS-Deiak) Coordination Center $24 / 48 \mathrm{~h}$ prior to the occurrence of the episode. The first Euskalmet coastalmaritime warning bulletin was issued in May 2004; the first 


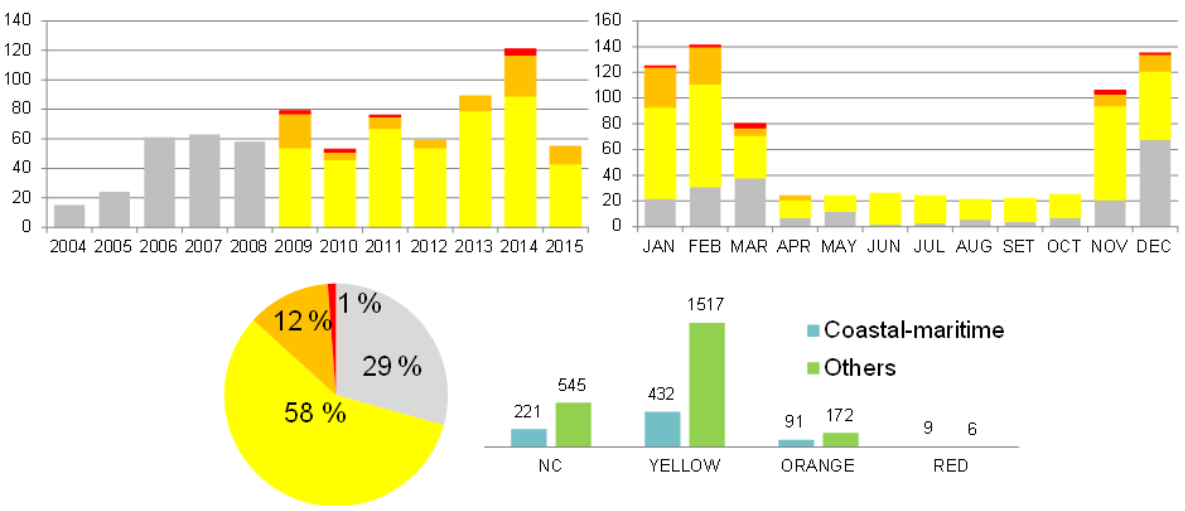

Figure 4. Yearly and monthly distribution of coastal-maritime warnings (April 2004-June 2015) in Basque Country, total distribution of warnings, and relative importance of oceanic and meteorological causes in the total warning system (from left to right and top to bottom panels).

new coastal-maritime warning bulletin based on new system was issued in March 2015 (Fig. 4). In 2011 we started to include Twitter in the warning dissemination procedures $(\mathrm{GV}$, 2011).

- In the case of "galernas", and due to its spatial and temporal characteristics, information is usually provided during the same day or the day before. It is important to properly specify the start time and how long it takes to sweep the entire Basque coast. Such warnings usually last for $2-5 \mathrm{~h}$. It is especially important that the information is transferred correctly to users of beaches and marinas. Monitoring is done using available coastal stations. Dissemination of real-time information via Twitter is very important.

- In the case of "navigation", predictability is usually high enough to disseminate information $48-72 \mathrm{~h}$ in advance. These episodes have an average duration of 1-3 days. It is important to include details of the expected sea conditions including swell, peak periods, and other sea state features.

- In the case of "coastal impact", although, in general, the predictability of tides (obviously), swells, and windwaves are often high, the exact conditions (significant wave height, peak period, etc.) at times of high tide and how they will affect to each point on the coast are less predictable. These warnings are usually issued $24-48 \mathrm{~h}$ prior to the event; they usually last for 3-4h (centred upon high tide) and usually contain extra explanations alerting for the dangerousness of temporal coincidence of the key factors.

\section{Conclusions}

In the Basque Country case, coastal-maritime risks denote a fundamental contribution to the whole warning system. Un- til mid-2015 they represented almost two-thirds of red level cases and more than one-third of the orange level cases (see Fig. 4). The presence of the concept of "coastal impact" on the system is essential when considering the adverse effects of waves in combination with spring tides.

Today, three different aspects are included in the coastalmaritime risk warning system for Basque Country, focusing on main potential severe events that affect Basque Country coastal area: "galerna" risk, a sudden wind reversal that can affect littoral activities, especially for beach and near-coast navigation and recreational activities; "navigation" risk, related to severe sea conditions for 0-2 miles, affecting different navigation activities; and "coastal impact" risk, related to adverse wave characteristics and spring tides that promote wave push and flooding impact in littoral areas.

Effective coastal-maritime early warnings systems may combine different products and communication strategies, with the final aim to facilitate actions from emergencies, civil protection, and other authorities and to ensure that people are warned in advance.

The Euskalmet coastal-maritime warning system is a local downstream service based on different downscaled operational ocean and meteorological models implemented in $\mathrm{Eu}-$ skalmet. The warning system could benefit in the near future from new wave products, based on relevant progress from R \& D outputs that will be implemented in the Copernicus Marine Service (She et al., 2016).

Acknowledgements. The authors would like to thank the Emergencies and Meteorology Directorate - Security Department - Basque Government for public provision of data and operational service financial support. We also would like to thank all our colleagues from Euskalmet for their daily effort in promoting valuable services for the Basque community.

Edited by: M. Grifoll

Reviewed by: two anonymous referees 


\section{References}

Egaña, J. and Gaztelumendi, S.: Destructive combination of strong waves and tides in the Basque Country: the 2 February 2014 case, 7th EuroGOOS Conference, 28-30 October 2014, Lisbon, 2014.

Egaña, J., Gaztelumendi, S., Gelpi, I. R., and Otxoa de Alda, K.: Analysis of oceano-meteorological conditions during Klaus episode on Basque Country area, 10th EMS/8th ECAC, 1317 September 2010, Zurich, 2010.

Egaña, J., Gaztelumendi, S., Ruiz, M., Pierna, D., Igelpi, I. R., and Otxoa De Alda, K.: Analysis of BECKY episode on Basque Country coastal area, 6th EuroGOOS Conference, 4-6 October 2011, Sopot, 2011.

Egaña, J., Gaztelumendi, S., and Hernández, R.: Analysis of 2014 winter patterns and its effects in Basque Country coastal area, 14th EMS/10th ECAC, 6-10 October 2014, Prague, 2014.

Ferrer, L., González, M., Grifoll, M., Fontán, A., Mader, J., Uriarte, A., Gaztelumendi, S., Egaña, J., Rodríguez, I., and Otxoa de Alda, K.: Towards 2010 strategy: oceanographic and meteorological modelling programme in the Basque Country, 5th EuroGOOS Conference, 20-22 May 2008, Exeter, UK, 4 pp., 2008.

Ferrer, L., González, M., Fontán, A., Mader, J., Uriarte, A., Gaztelumendi, S., Egaña, J., Gelpi, I. R., Otxoa de Alda, K., Morais, A., and Aranda, J. A.: Towards a future strategy in oceanography and meteorology for the Basque Country, GLOBEC Int. Newslett., 15, 54-55, 2009.

Gaztelumendi, S. and Egaña, J.: Analysis of maritime-coastal severe events in Basque Country during 2014 winter, 7th EuroGOOS Conference, 28-30 October 2014, Lisbon, 2014.

Gaztelumendi, S., Ega na, J., Gelpi, I. R., and Otxoa de Alda, K.: The EUSKALMET wave forecast system - preliminary results and validation, 5th EuroGOOS Conference, 20-22 May 2008, Exeter, 2008.

Gaztelumendi, S., González, J., Egaña, J., Rubio, A., Gelpi, I. R., Fontán, A., Otxoa De Alda, K., Ferrer, L., Alchaarani, N., Mader, J., and Uriarte, A.: Implementation of an operational OcéanoMeteorological system for the Basque country, Thalassas, 26, 151-167, 2010

Gaztelumendi, S., Egaña, J., Ruiz, M., Pierna, D., Otxoa De Alda, K., and Gelpi, I. R.: An analysis of Cantabric coastal trapped disturbances, 6th EuroGOOS Conference, 4-6 October 2011, Sopot, 2011.
Gaztelumendi, S., Egaña, J., Hernandez, R., Otxoa de Alda, K., Aranda, J. A., and Anitua, P.: An overview of a regional meteorology warning system, Adv. Sci. Res., 8, 157-166, 2012.

Gaztelumendi, S., Orbe, I., Lopez, A., Aranda, J. A., and Anitua, P.: Social media and high impact weather communication in Basque Meteorology Agency, 13th EMS/11th ECAM, 913 Septmber 2013, Reading, UK, 2013.

Gaztelumendi, S., Egaña, J., Gelpi, I. R., Carreño, S., Gonzalez, M., Liria, P., Rodriguez, G., Epelde, I., Rubio, A., and Aranda, J. A.: Characterization of coastal-maritime severe events in Basque Country, 7th EuroGOOS Conference. 28-30 October 2014, Lisboa, Portugal, 2014.

Gaztelumendi, S., Martija, M., Príncipe, O., and Palacio, V.: An overview of the use of Twitter in National Weather Services, Adv. Sci. Res., 12, 141-145, 2015.

Gaztelumendi, S., Orbe, I., Salazar, O., Lopez, A., Aranda, J., and Anitua, P.: Delivery and communication of severe weather events in Basque Country: the Euskalmet case, Adv. Sci. Res., accepted, 2016.

GV: Plan de predicción y vigilancia de fenómenos meteorológicos adversos, internal procedures from Basque Government, 2004, 2009, 2011, 2014, 2015.

Liria, P., Epelde, I., Gaztelumendi, S., Egaña, J., Gelpi, I. R., Carreño, S., Gonzalez, M., and Aranda, J.: Los temporales de enero, febrero y marzo de 2014 dentro del contexto del clima marino de la costa vasca. Efectos sobre las infraestructuras costeras y las playas, XVI Congreso y Exposición ECOPLAYAS, 5-7 November 2014, Bilbao, 2014.

She, J., Allen, I., Buch, E., Crise, A., Johannessen, J. A., Le Traon, P. Y., Lips, U., Nolan, G., Pinardi, N., Reißmann, J. H., Siddorn, J., Stanev, E., and Wehde, H.: Developing European operational oceanography for Blue Growth, climate change adaptation and mitigation and ecosystem-based management, Ocean Sci. Discuss., doi:10.5194/os-2015-103, in review, 2016.

Stockdon, H. F., Holman, R. A., Howd, P. A., and Sallenger, A. H.: Empirical parametrization of setup, swash and run up, Coast. Eng., 53, 573-588, 2006.

WMO: Guide on Improving Public Understanding of and Response to Warnings, WMO/TD 1139, Switzerland, 28 pp., 2002.

WMO: Guidelines on early warning systems and application of nowcasting and warning operations, WMO/TD 559, Switzerland, 22 pp., 2010. 